\title{
Synthesis and Microbial Activity of Manganese (II) and Cobalt (III) Complexes of 3-Methoxy-4- Hydroxyphenylmethyelene (2- Hydroxyphenyl) Amine
}

\author{
Belachew Kebede \\ College of Natural and Computational Sciences, Debre Berhan University, Debre Berhan, Ethiopia
}

\section{Email address:}

bktdbr84@gmail.com

\section{To cite this article:}

Belachew Kebede. Synthesis and Microbial Activity of Manganese (II) and Cobalt (III) Complexes of 3-Methoxy-4Hydroxyphenylmethyelene (2- Hydroxyphenyl) Amine. American Journal of Applied Chemistryh. Vol. 7, No. 3, 2019 , pp. 95-103. doi: 10.11648/j.ajac.20190703.13

Received: March 26, 2019; Accepted: April 30, 2019; Published: June 26, 2019

\begin{abstract}
Transition metal complexes of Mnanganese (II) and Cobalt (III) were synthesized from the Schiff's base ligand, 3methoxy-4-hydroxyphenylmethyelene (2-hydroxyphenyl) amine which is derived from vanillin and 2-aminohpenol by the reaction of the metal ions. The Structural features of these complexes were obtained from their elemental analyses, magnetic susceptibility, molar conductance, FT-IR, electronic spectra, and Atomic Absorption Spectroscopic studies. In order to study the binding modes of the ligand (Schiff's base) with metal ions in the complexes, the FT- IR spectrum of the free ligand was compared with the spectra of its complexes. The spectral data suggest the involvement of phenolic oxygen and azomethane nitrogen in coordination to the central metal ions. On the basis of spectral studies and magnetic susceptibility measurements, an octahedral geometry has been assigned for both complexes. The free ligand and its metal complexes were tested in vitro against bacteria (Escherichia coli, Staphylococcus aureus) and fungi (Aspergillus Niger, Colletotricum) in order to assess their antimicrobial activities. And the results indicated that all compounds are effective against both tested bacteria and fungi though their effects are dose dependent. The free ligand showed higher activities than its complexes in both bacteria and fungi case, which suggests the promising potential of the ligand for both bacterial and fungi test.
\end{abstract}

Keywords: Antimicrobial Activities, Schiff's Base Ligand, Spectral Studies, Transition Metal Complexes

\section{Introduction}

A metal complex consists of a central metal atom or ion bonded to a surrounding array of neutral molecules or anions, ligands or complexing agents bearing lone pairs of electrons. Coordination complexes were not known till 1893 and came to picture when Alfred Werner proposed in 1893 that Co (III) bears six ligands (ammonia and/or chloride) in an octahedral geometry. Transition metal complexes of organic compounds are structurally known to possess considerable potential in many applications including pharmacological, analytical [1], catalytic [2], microbial [3], insecticidal, growth factors, food additive, tumor inhibitors and cell divisions [4]. These multifarious features of complexes are either due to the unused coordination sites present on the metal and ligand systems, or due to the selective oxidation state of the complexed metal ions in the coordination sphere [5].
Among the variety of organic ligands, Schiff's bases named after Von Schiff are compounds with azomethine functional group $(-\mathrm{C}=\mathrm{N}-)$ with $\mathrm{N}$ atom connected to an aryl or alkyl group are preponderant over others owing to high stability of their complexes with transition metals, mainly first series transition metal ions [6]. Schiff's base in a broad sense is one having the general formula $R^{1} R^{2} C=N R^{3}$, where $\mathrm{R}$ is an organic side chain. But some restrict the term to the secondary aldimines (azomethines where the carbon is connected to a hydrogen atom), thus with the general formula $\mathrm{RCH}=\mathrm{NR}$. The chain on $\mathrm{N}$ atom makes the Schiff's base a stable imine. Schiff's bases that contain aryl substituents are relatively more stable and more readily synthesized, while those containing alkyl substituents are relatively unstable [7].

A Schiff's base derived from aniline, where $\mathrm{R}^{3}$ is a phenyl or substituted phenyl can be called an anil compound by nucleophilic forming hemiaminal, followed by a dehydration 
to generate an imine. Schiff's bases have acquired highest popularity as ligands among all the different classes of organic compounds owing to their multifarious roles in diverse fields of development. A few of the manifold distinguished features can be summarized to manifest their high importance. High electron donor ability and bathochromicproperties of Schiff's bases have led to their use in analytical chemistry as gravimetric and colorimetric reagents and as metallic indicators in complexometric titration [8]. In industries azomethines and their complexes are popular pigments and dyes for cotton, wool, synthetic fibers and plastics. Many Schiff's bases having thermal stability up to $25^{\circ} \mathrm{C}$ could be used as high temperature stabilizers for lubricating oils [9]. Oil soluble Schiff's bases have been used as sequestering agents to precipitate metal impurities of oils. Azomethines are effective inhibitors against acid corrosion of metals and alloys. These compounds are also used as photographic developing agent precursors. Schiff's bases having enolic groups are well known drying accelerators for varnishes and paints. Thin film of polyamide imides Schiff's base copolymers prepared at high temperatures and low pressures have been reported to possess strong fire resisting capacity. In synthetic organic chemistry Schiff's bases have vital use as starting materials or as intermediates.

Anticancerous [10], anti-tuberculosis [11], antiinflammatory [12], rust inhibitors, antibacterial, fungicidal [13], antiviral, antibiotic, aesthetic etc. biological activities of Schiff's bases and their complexes, lead to their medicinal uses [14]. Most common Schiff bases have $\mathrm{NO}$ or $\mathrm{N}_{2} \mathrm{O}_{2}$ donor atoms but $\mathrm{NS}, \mathrm{NN}, \mathrm{ONO}, \mathrm{NNO}$, donor sequences are also possible. Substituted Schiff's bases are generally bidentate, tridentate, tetradentate or polydentate ligands capable of forming very stable cyclic complexes called chelates with transition metals [15].

Although a large number of complexes of transition and non-transition metals with a variety of Schiff's base derivatives as ligands have been synthesized and characterized for their structures and various properties, complexes of Co (III) and $\mathrm{Mn}$ (II) resulted from condensation product of vanillin with ortho hydroxyaniline has not been reported hitherto. In this article, the researcher presents the synthesis, characterization and antimicrobial study of the ligand of interest and its Co (III) and Mn (II) complexes.

\section{Materials and Methods}

\subsection{Reagents and Chemicals}

All the chemicals used in this study were analytical grade. Solutions of PDA (potato dextrose agar), Mueller hinton agar (MHA) were prepared in the laboratory. Solvents in synthetic work were used as supplied whereas in spectroscopic and thin layer chromatographic work all solvents were HPLC grade.

\subsection{Characterization Techniques}

The infrared spectra were recorded on Fourier Transform
Infrared (FT-IR) spectrophotometer (prestige-21) in the range 4000-200 $\mathrm{cm}^{-1}$. C, H, N elemental analyses were done with a Carlo Erba Model EA1108 analyzer. Molecular weights of the ligand and its complexes were determined by Rast's method using camphor as a solvent. The melting points of the synthesized compounds were determined in an open glass capillaries using Bibby Sterilin LTD, ST150SA, UK melting point apparatus. Electronic spectral measurements were done using UV/Vis-SP65 SYANO spectrophotometer in 200-800 $\mathrm{nm}$ range. Magnetic susceptibility measurements were done using MSB-AUTO, (Sherwood Scientific) magnetic balance.

The molar conductivity measurements were carried out using Jenway digital conductivity meter (UK). Antimicrobial evaluation was performed for the ligand and both complexes.

\subsection{Experimental Procedures}

\subsubsection{Synthesis of 3-Methoxy-4-Hydroxyphenyl Methyelene (2-Hydroxyphenyl) Amine}

The ligand, 3-methoxy-4-hydroxyphenylmethyelene (2hydroxyphenyl) amine was prepared by the condensation reaction of vanillin and 2-aminophenol. Vanillin (7.6 g, 0.05 mol) and 2-aminophenol (5.8 g, $0.053 \mathrm{~mol})$ were mixed together in dry alcohol and refluxed for $2 \mathrm{~h}$ in round bottom flask. Reaction mixture was concentrated on water bath and cooled. Saddle brown solid precipitated was filtered out and washed with diethyl ether repeatedly to remove unreacted amine if any. Product was crystallized from alcohol and dried in oven at $75^{\circ} \mathrm{C}[16]$.

\subsubsection{Synthesis of the Metal Complexes}

The metal complexes of Co (III) and Mn (II) were prepared by mixing the saturated ethanolic solutions of the respective metal chlorides $(0.005 \mathrm{~mol})$ and the ligand $(0.005 \mathrm{~mol})$ in 150 $\mathrm{mL}$ beaker. The solution was heated in water bath at about 75 ${ }^{0} \mathrm{C}$ with continuous stirring to remove the solvent. After evaporation of the solvent, both complexes were washed several times with water to remove unreactive metal if any, to get the pure product. Finally, both the products were dried in air and recrystallized from ethanol [17].

\subsection{Antimicrobial Evaluation}

Antimicrobial (antibacterial and antifungal) activities of the ligand and its complexes were tested in vitro against two bacteria and two fungi using disc diffusion method. The two bacteria and fungi were cultivated on Mueller hinton agar (MHA) and potato dextrose agar medium respectively. The degree of bactericidal and fungicidal activities was determined by measuring diameter of inhibition zone and compared with the standard drug chloramphenicol and bavistin respectively [18].

\subsubsection{Inoculums Preparation}

The test bacterial strains, Escherichia coli (Gram-negative) and Staphelococus aureus (Gram-positive), were transferred from the stock cultures and streaked on Mueller Hinton agar (MHA) plates and incubated for about $24 \mathrm{~h}$. Bacteria were transferred using bacteriological loop to autoclaved MHA 
that was cooled to about $45^{\circ} \mathrm{C}$ in water bath and mixed by gently swirling the flasks. The medium was then poured to sterile Petri dishes, allowed to solidify and used for the biotest. For test fungi, mycelia plugs from the stock cultures were transferred to PDA plates and incubated for 6 days. Then spores of the test fungi names were harvested by washing the surface of the colony using $10 \mathrm{ml}$ sterile distilled water and transferred to $50 \mathrm{~mL}$ autoclaved PDA cooled to about $45^{\circ} \mathrm{C}$ in a water bath. The medium containing spore suspension was poured to sterile plates, allowed to solidify and was used for the paper disc diffusion bioassay.

\subsubsection{Antifungal Activity}

Paper discs about $3 \mathrm{~mm}$ in diameter were cut from Whatman-1 filter paper with an office paper punch and placed in a beaker covered with aluminium foil and sterilized in an oven at $180^{\circ} \mathrm{C}$ for $1 \mathrm{~h}$. Aliquots of $10 \mu \mathrm{L}$ and $20 \mu \mathrm{L}$ of the sample solutions of ligand and its complexes were pipetted to the discs in three replications each. The paper discs impregnated with the sample solutions were then transferred using sterile forceps to PDA seeded with spore suspension of test fungi as described under inoculums preparation above. The petri dishes were incubated at $26^{\circ} \mathrm{C}$ for 6 days. All the tests were performed in triplicate. The effectiveness of the samples was evaluated by measuring inhibition zone against the tested organisms.

\subsubsection{Antibacterial Activity}

Similar procedures were followed for testing antibacterial activities. Paper discs were transferred to Mueller Hinton agar (MHA) plate seeded with bacteria and incubated at $37^{\circ} \mathrm{C}$ for $24 \mathrm{~h}$. All the tests were performed in triplicate. Antibacterial activity was evaluated by measuring the zone of inhibition against the tested organisms.

\section{Results and Discussion}

The ligand, 3-methoxy-4-hydroxyphenylmethyelene (2hydroxyphenyl)amine was prepared by the condensation reaction of vanillin and 2-aminophenol as presented in Figure 1. The precipitated saddle brown solid of the ligand reacted with the metal chlorides which yield the complexes. Both the synthesized complexes and the ligand were screened for their antibacterial and antifungal activities.

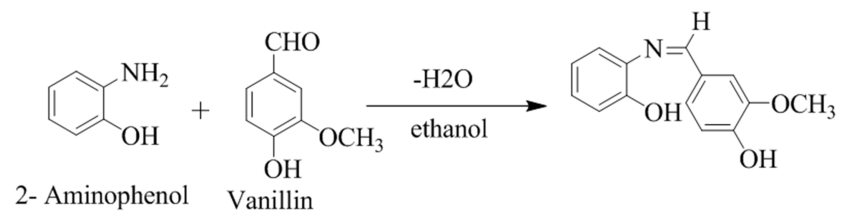

Figure 1. Synthesis of 3-methoxy-4-hydroxyphenylmethyelene (2hydroxyphenyl) amine.

Colour, melting point, yield and analyses data of ligand and its complexes are noted in (Table 1). It is clear from the data that the experimental values shown for the ligand and each of the complexes, are in good agreement with the theoretical values calculated. The proposed molecular formulae of ligand and its complexes are in conformity with their molecular weights (Table 2).

Table 1. Chemical formula, molecular weight, color, melting point, yield and analyses data of compounds.

\begin{tabular}{|c|c|c|c|c|c|c|c|c|}
\hline \multirow{2}{*}{ Compounds } & \multirow{2}{*}{ MW Calc. (Found) } & \multirow{2}{*}{ Color } & \multirow{2}{*}{$\mathrm{MP}\left({ }^{\circ} \mathrm{C}\right)$} & \multirow{2}{*}{ Yield (\%) } & \multicolumn{3}{|c|}{ Analysis Calc. (Found)\% } & \multirow{2}{*}{ metal\% } \\
\hline & & & & & $\mathrm{C}$ & $\mathbf{H}$ & $\mathbf{N}$ & \\
\hline $\mathrm{C}_{14} \mathrm{H}_{13} \mathrm{NO}_{3}$ & $243(239)$ & Saddle brown & $106 \pm 1$ & 70 & $69.13(67.26)$ & $5.35(6.63)$ & $5.76(5.09)$ & - \\
\hline $\mathrm{Mn}$ & $647(651)$ & Brown & $114 \pm 1$ & 64 & $51.61(52.57)$ & $5.53(5.27)$ & $4.30(3.95)$ & $8.75(8.95)$ \\
\hline
\end{tabular}

Mn: $\left[\mathrm{Mn}\left(\mathrm{C}_{14} \mathrm{H}_{12} \mathrm{NO}_{3}\right)_{2}\left(\mathrm{H}_{2} \mathrm{O}\right)_{2}\right] .4 \mathrm{H}_{2} \mathrm{O}, \mathrm{Co}:\left[\mathrm{Co}\left(\mathrm{C}_{14} \mathrm{H}_{12} \mathrm{NO}_{3}\right)_{2}\left(\mathrm{H}_{2} \mathrm{O}\right) \mathrm{Cl}\right] .2 \mathrm{H}_{2} \mathrm{O}$, MW: molecular weight, MP: melting point.

Table 2. Molecular weight Determination Data.

\begin{tabular}{|c|c|c|c|c|c|}
\hline \multirow{2}{*}{ Compounds } & \multirow{2}{*}{ Freezing point of mixture (camphor + complexes $\left.\left({ }^{\circ} \mathrm{C}\right)\right)$} & \multirow{2}{*}{$\begin{array}{l}\text { Depression in freezing point of } \\
\text { camphor }\left(\Delta T_{f}\right)\left({ }^{\circ} \mathrm{C}\right)\end{array}$} & \multicolumn{2}{|c|}{ Molecular weight (g/mol) } & \multirow{2}{*}{$\begin{array}{l}\text { Error } \\
(\%)\end{array}$} \\
\hline & & & Calc. & Found & \\
\hline $\mathrm{C}_{14} \mathrm{H}_{13} \mathrm{NO}_{3}$ & 161.4 & 16.6 & 243 & 239.0 & 1.60 \\
\hline $\mathrm{Mn}$ & 171.0 & 5.0 & 647 & 651.0 & 0.62 \\
\hline Co & 173.7 & 2.3 & 632.5 & 628.0 & 0.71 \\
\hline
\end{tabular}

$\mathrm{Mn}:\left[\mathrm{Mn}\left(\mathrm{C}_{14} \mathrm{H}_{12} \mathrm{NO}_{3}\right)_{2}\left(\mathrm{H}_{2} \mathrm{O}\right)_{2}\right] .4 \mathrm{H}_{2} \mathrm{O}, \mathrm{Co}:\left[\mathrm{Co}\left(\mathrm{C}_{14} \mathrm{H}_{12} \mathrm{NO}_{3}\right)_{2}\left(\mathrm{H}_{2} \mathrm{O}\right) \mathrm{Cl}\right] .2 \mathrm{H}_{2} \mathrm{O}$, Freezing point of Camphor $=178{ }^{\circ} \mathrm{C}$, Mixtures of freezing points are mean values of three observations.

Conductance of standard solutions of complexes of 1000 ppm concentration in ethanol was measured at room temperature and molar conductance was calculated (table 3). Molar conductance values reveal non-electrolytic nature of all the complexes [19]. For verification of conduct metric results silver nitrate test on the solutions of complexes was also performed. On mixing the solutions of complexes with $\mathrm{AgNO}_{3}$ solution in water- ethanol $(3: 2 \mathrm{v} / \mathrm{v})$ white precipitate of $\mathrm{AgCl}$ was not obtained; absence of any ionic chlorine is consistent with their non-electrolytic nature. However, the presence of coordinated chlorine in complexes has been tested by decomposing the complexes with conc. $\mathrm{HNO}_{3}$ and treating their acidic solutions with aqueous solution of $\mathrm{AgNO}_{3}$. In the case of $\mathrm{Co}$ (III) white precipitate of $\mathrm{AgCl}$ was obtained indicating coordination of chlorine with this metal. 
Table 3. Molar conductivity measurement data.

\begin{tabular}{|c|c|c|c|c|}
\hline Complexes & Conductance of complex $(\mu \mathrm{S})$ & Specific conductance $x^{10}{ }^{6}\left(\mathrm{Ohm} \mathrm{cm}^{2} \mathrm{~mol}^{-1}\right)$ & Molar conductance $\left(\Omega^{-1} \mathrm{~cm}^{2} \mathrm{~mol}^{-1}\right)$ & Electrolytic nature \\
\hline $\mathrm{Mn}$ & 4.44 & 4.396 & 2.85 & $\mathrm{NE}$ \\
\hline Co & 6.90 & 6.831 & 4.29 & NE \\
\hline
\end{tabular}

Mn: $\left[\mathrm{Mn}\left(\mathrm{C}_{14} \mathrm{H}_{12} \mathrm{NO}_{3}\right)_{2}\left(\mathrm{H}_{2} \mathrm{O}\right)_{2}\right] .4 \mathrm{H}_{2} \mathrm{O}, \mathrm{Co}:\left[\mathrm{Co}\left(\mathrm{C}_{14} \mathrm{H}_{12} \mathrm{NO}_{3}\right)_{2}\left(\mathrm{H}_{2} \mathrm{O}\right) \mathrm{Cl}\right] \cdot 2 \mathrm{H}_{2} \mathrm{O}$, NE: non-electrolyte, Cell constant $(\mathrm{k})=0.99$, Conductance of ethanol $=4 \times 10^{-7} \Omega^{-1}$

The metal content in the complexes were determined using atomic absorption spectrophotometer (AAS). Metal percentage along with analyses data was used to arrive at the metal-ligand ratio in the complex. For this purpose, $20 \mathrm{mg}$ of each complex were digested completely in conc. HNO3 till nearly colorless solution was obtained and analyzed by AAS. The experimental percentage of metal in the complexes was found as:

$$
=\frac{\text { Concentration }(\mathrm{ppm}) \times \text { Volume diluted to }}{\text { Mass of sample taken }} \times \frac{100}{1000}
$$

The data obtained from AAS (Table 4), shows that metal to ligand ratio in both $\mathrm{Mn}$ (II) and Co (III) complexes is 1:2 ratio.

\begin{tabular}{|c|c|c|c|c|c|}
\hline \multirow{2}{*}{ Compounds } & \multirow{2}{*}{ Molecular weight } & \multirow{2}{*}{ Conc. (ppm) } & \multirow{2}{*}{ Sample absorbance (nm) } & \multicolumn{2}{|c|}{$\%$ metal } \\
\hline & & & & Calc. & Found \\
\hline $\mathrm{Mn}$ & 647 & 18.50 & 0.303 & 9.11 & 9.16 \\
\hline Co & 632.5 & 17.30 & 0.396 & 8.87 & 8.70 \\
\hline
\end{tabular}

Table 4. AAS data.

$\mathrm{Mn}:\left[\mathrm{Mn}\left(\mathrm{C}_{14} \mathrm{H}_{12} \mathrm{NO}_{3}\right)_{2}\left(\mathrm{H}_{2} \mathrm{O}\right)_{2}\right] .4 \mathrm{H}_{2} \mathrm{O}, \mathrm{Co}:\left[\mathrm{Co}\left(\mathrm{C}_{14} \mathrm{H}_{12} \mathrm{NO}_{3}\right)_{2}\left(\mathrm{H}_{2} \mathrm{O}\right) \mathrm{Cl}\right] .2 \mathrm{H}_{2} \mathrm{O}$.

\subsection{Infrared Spectra}

In order to study the binding mode of ligand (Schiff's base) with metal ions in the complexes, the FT- IR spectrum of the free ligand was compared with the spectra of its complexes (table 5). Bands at $3376 \mathrm{~cm}^{-1}$ and $3305 \mathrm{~cm}^{-1}$ assigned to phenolic $v(\mathrm{OH})$ in ligand spectrum have also been identified in complex spectra in $3294-3447 \mathrm{~cm}^{-1}$ region with broad or doublet structure. Although appearance of phenolic $v(\mathrm{OH})$ bands in complex spectra does not show involvement of phenolic group of ligand in coordination but on the basis of appearance of new peaks in 527-596 $\mathrm{cm}^{-1}$ range, attributed to $v$ (M-O), coordination of one of the deprotonated phenolic group(most probably in ortho position to azomethine group) can be evidence for its coordination. Substantial lowering in free ligand band at $1639 \mathrm{~cm}^{-1}$ corresponding to azomethine $(\mathrm{C}=\mathrm{N})$ stretching on complexation clearly indicates coordination of azomethine nitrogen with metal ions; a new band in $456-517 \mathrm{~cm}^{-1}$ in complex spectra supports the coordination of azomethine group of the ligand.

In the spectrum of Co (III) complex a new band at $330 \mathrm{~cm}^{-1}$ assigned to terminal $v(\mathrm{Co}-\mathrm{Cl})$ The presence of lattice water in these complexes is supported by the presence of new peaks in $1640-1670 \mathrm{~cm}^{-1}$ region owing to symmetric and asymmetric bending vibrations of lattice water [20]. The presence of water in the coordination zone of both Co (III) and $\mathrm{Mn}$ (II) complexes is indicated by the appearance of one to three new bands in $856-980 \mathrm{~cm}^{-1}$ range in their spectra; one new band observed in $251-268 \mathrm{~cm}^{-1}$ region due to $v\left(\mathrm{M}-\mathrm{H}_{2} \mathrm{O}\right)$ supports the coordination of water molecule (s) with the metals.

\begin{tabular}{|c|c|c|c|c|c|}
\hline Compounds & $v(\mathrm{O}-\mathrm{H})$ & $v(\mathrm{C}-\mathrm{H})$ & $v(C=N)$ & $\mathbf{v}(\mathrm{C}=\mathrm{C})$ & $v(C-O)$ \\
\hline $\mathrm{C} 14 \mathrm{H} 13 \mathrm{NO} 3$ & $\begin{array}{l}3376 \\
3305\end{array}$ & 3054 & 1639 & $\begin{array}{l}1584 \\
1515 \\
1468\end{array}$ & $\begin{array}{l}1124 \\
1084 \\
1027\end{array}$ \\
\hline Co & $3374 \mathrm{br}$ & 2966 & 1588 & $\begin{array}{l}1588 \\
1515 \\
1463\end{array}$ & $\begin{array}{l}1126 \\
1130\end{array}$ \\
\hline $\mathrm{Mn}$ & 3294 br & $\begin{array}{l}3001 \\
2950\end{array}$ & 1584 & $\begin{array}{l}1517 \\
1452\end{array}$ & $\begin{array}{l}1123 \\
1026\end{array}$ \\
\hline
\end{tabular}

Table 5. IR frequencies $\left(\mathrm{cm}^{-1}\right)$ characteristics groups of the ligand and its complexes.

\begin{tabular}{|c|c|c|c|c|c|c|c|c|}
\hline Compounds & $\begin{array}{l}\text { Sym. \& antisym. } \\
\text { Stretching }\end{array}$ & $\begin{array}{l}\text { Sym. \& antisym } \\
\text { bending }\end{array}$ & $\begin{array}{l}\rho_{t H 2 O}, \rho_{w}(H 2 O) \& \rho_{r} \\
(H 2 O)\end{array}$ & $v(M-O)$ & $v(M-N)$ & $v\left(\mathrm{M}-\mathrm{OH}_{2}\right)$ & $v(M-C l)$ & $\begin{array}{l}\text { Benzene ring } \\
\text { disubstitute }\end{array}$ \\
\hline $\mathrm{C}_{14} \mathrm{H}_{13} \mathrm{NO}_{3}$ & 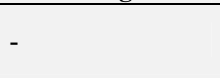 & 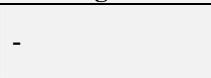 & (c) & - & - & - & - & $\begin{array}{l}763(\mathrm{o}) \\
823(\mathrm{p})\end{array}$ \\
\hline $\mathrm{Co}$ & 3374 br & - & $\begin{array}{l}978 \\
856\end{array}$ & 567 & 458 & 268 & 330 & $\begin{array}{l}757(\mathrm{o}) \\
817(\mathrm{p})\end{array}$ \\
\hline $\mathrm{Mn}$ & $3294 \mathrm{br}$ & 1640 & $\begin{array}{l}980 \\
938 \\
874\end{array}$ & 596 & 517 & 254 & - & $\begin{array}{l}748(\mathrm{o}) \\
821(\mathrm{p})\end{array}$ \\
\hline
\end{tabular}

Table 5. Continue.

$\mathrm{Mn}:\left[\mathrm{Mn}\left(\mathrm{C}_{14} \mathrm{H}_{12} \mathrm{NO}_{3}\right)_{2}\left(\mathrm{H}_{2} \mathrm{O}\right)_{2}\right] \cdot 4 \mathrm{H}_{2} \mathrm{O}, \mathrm{Co}:\left[\mathrm{Co}\left(\mathrm{C}_{14} \mathrm{H}_{12} \mathrm{NO}_{3}\right)_{2}\left(\mathrm{H}_{2} \mathrm{O}\right) \mathrm{Cl}\right] .2 \mathrm{H}_{2} \mathrm{O}$. 


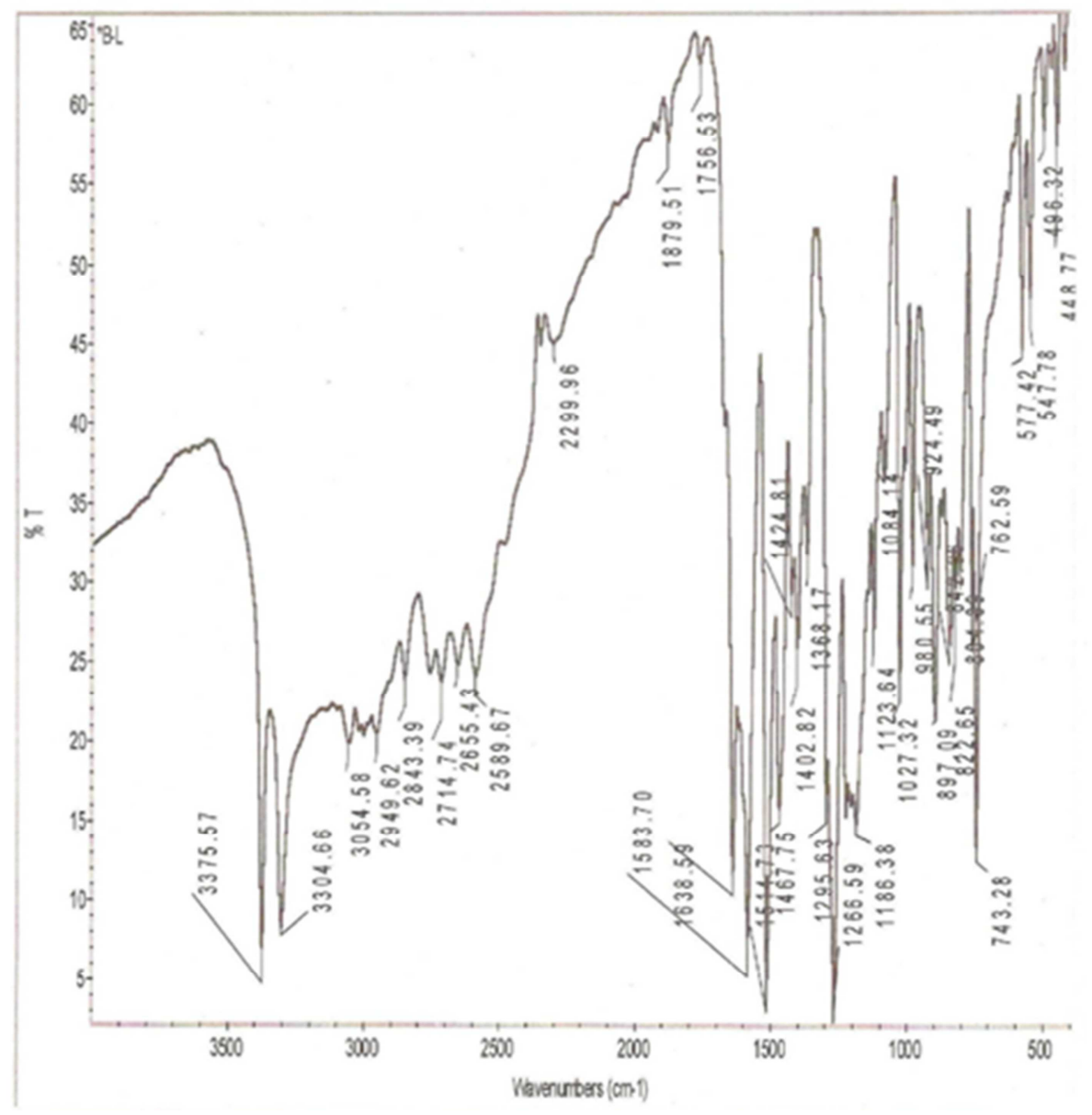

Figure 2. FTIR spectrum of $\mathrm{C}_{14} \mathrm{H}_{13} \mathrm{NO}_{3}$.

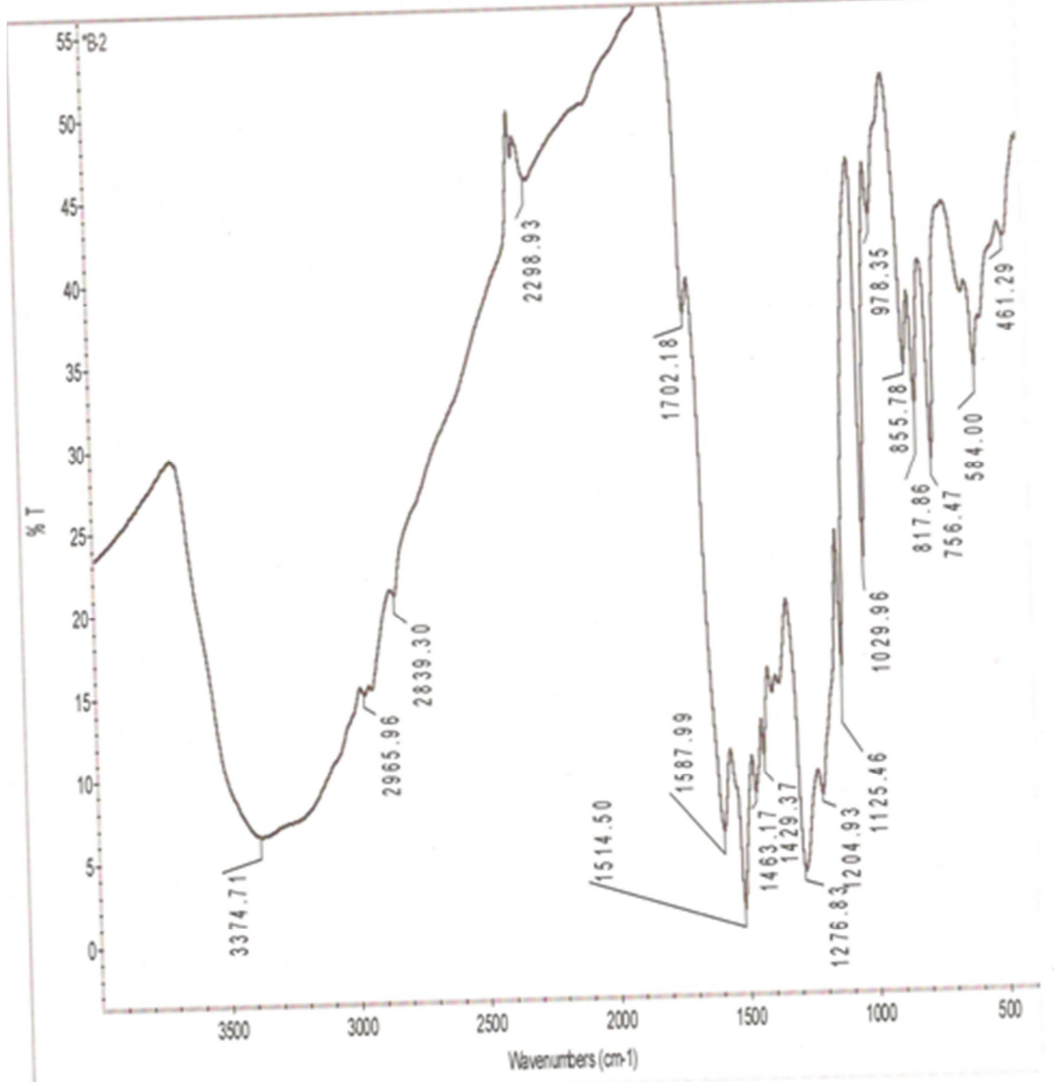




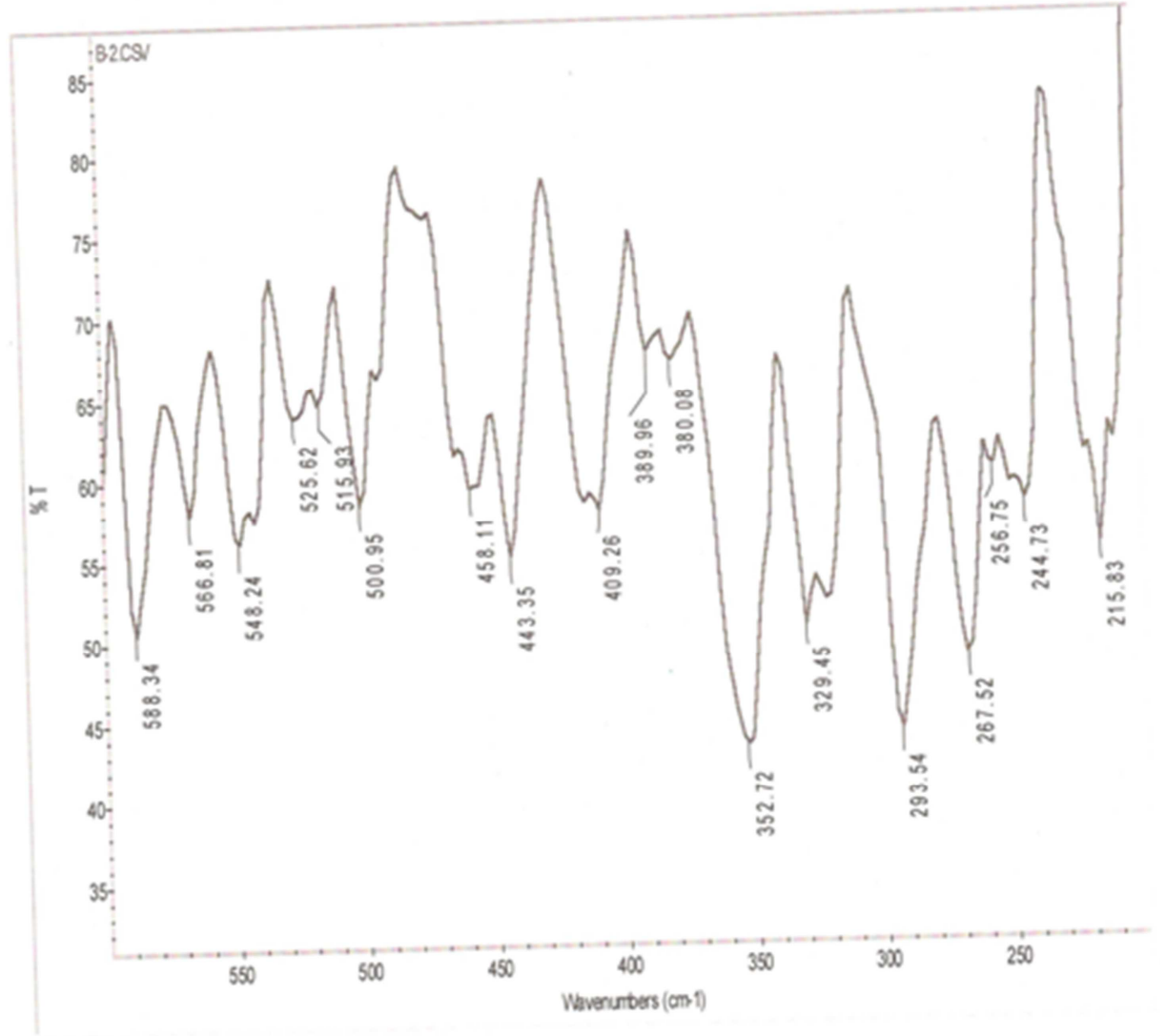

Figure 3. FTIR spectrum of $\left[\mathrm{Co}\left(\mathrm{C}_{14} \mathrm{H}_{12} \mathrm{NO}_{3}\right)_{2}\left(\mathrm{H}_{2} \mathrm{O}\right) \mathrm{Cl}\right] .2 \mathrm{H}_{2} \mathrm{O}$

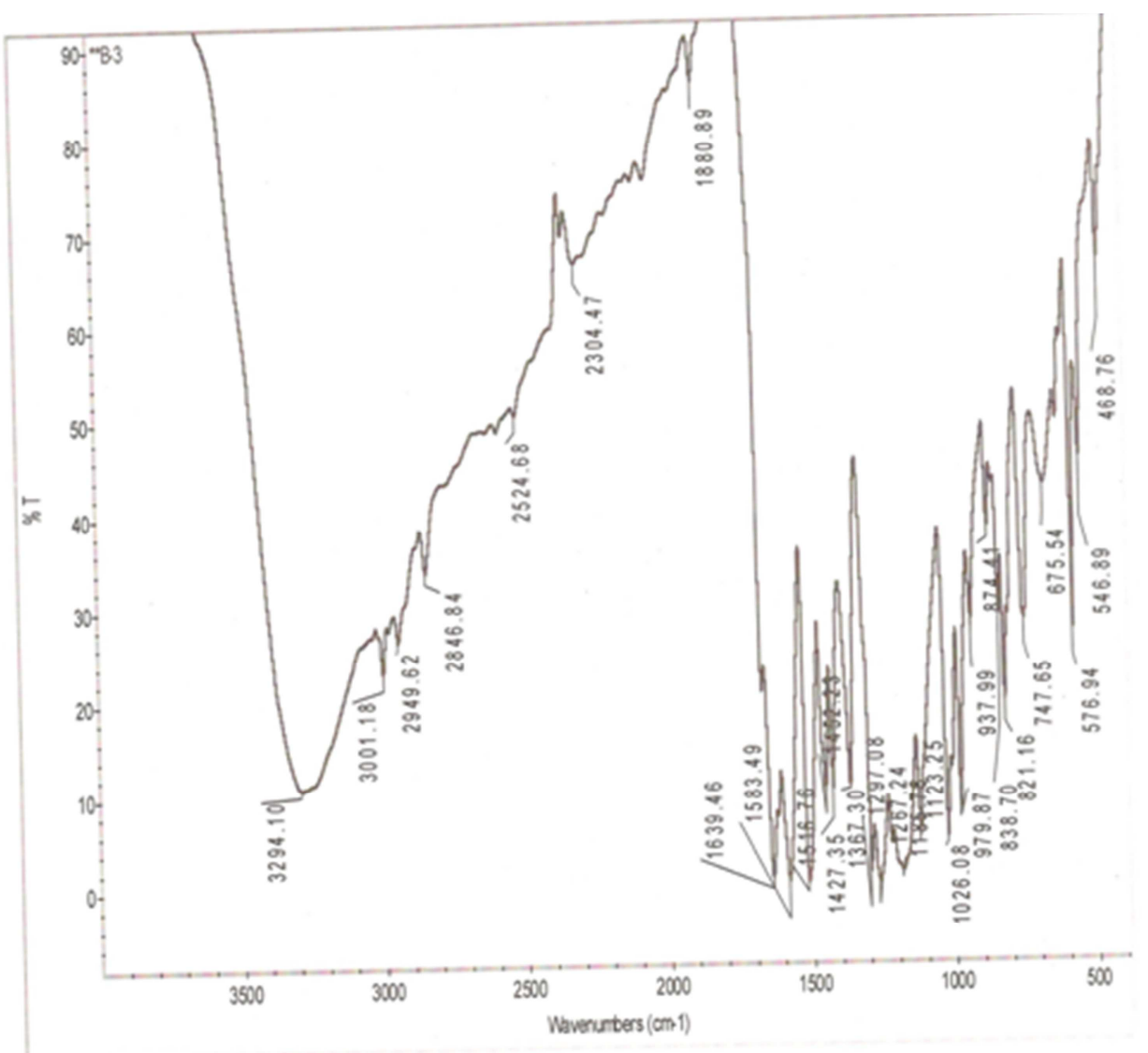




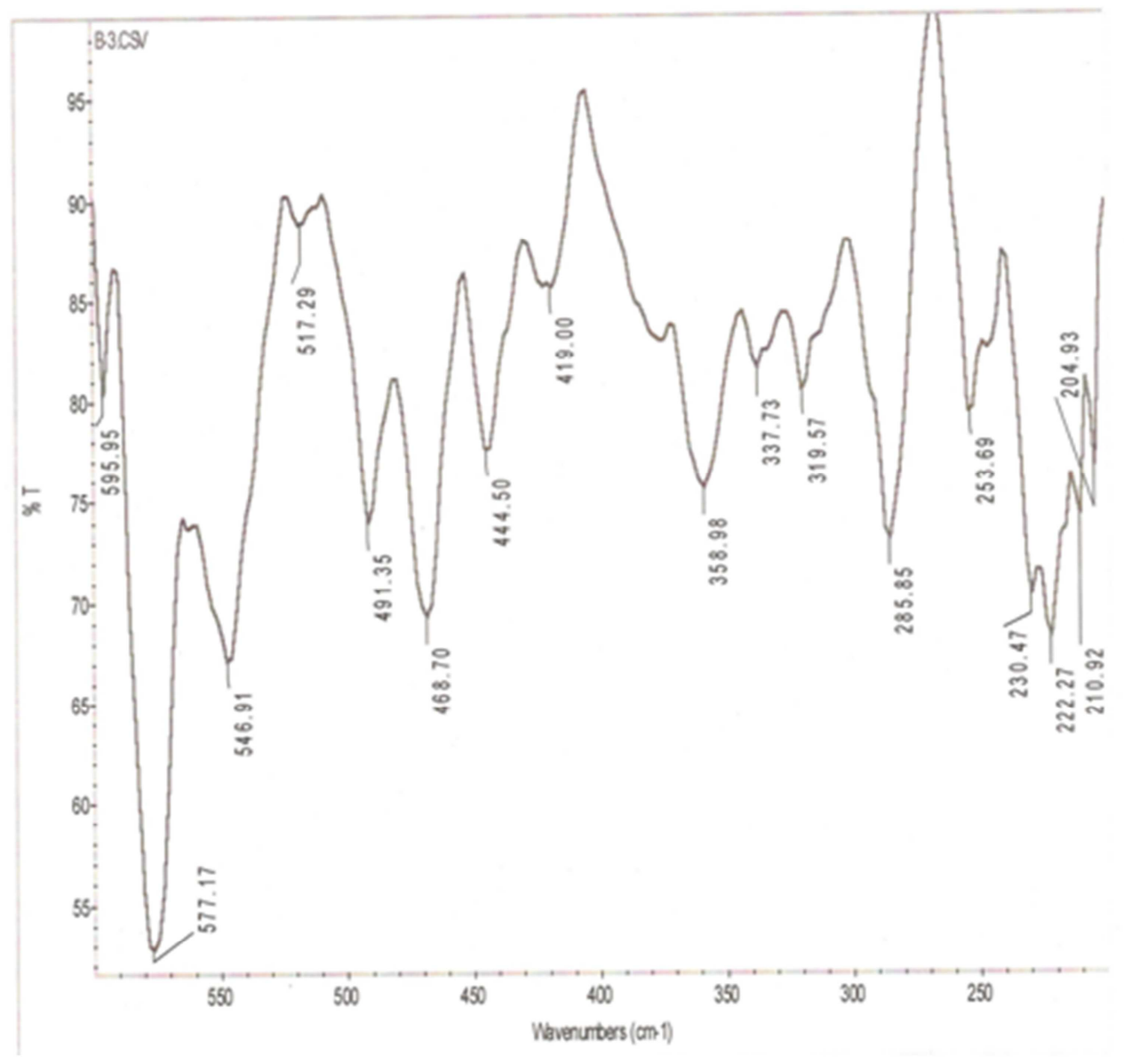

Figure 4. FTIR spectrum of $\left[\mathrm{Mn}\left(\mathrm{C}_{14} \mathrm{H}_{12} \mathrm{NO}_{3}\right)_{2}\left(\mathrm{H}_{2} \mathrm{O}\right)_{2}\right] \cdot 4 \mathrm{H}_{2} \mathrm{O}$.

\subsection{Electronic (UV-Vis) Spectra and Magnetic Moments}

The magnetic moment of Co(III) complex, 4.89 BM consistent with $\mathrm{S}=2$ ground stat in an octahedral field. Co (III) is a $\mathrm{d}^{6}$ system and complexes can be high spin or low spin depending upon the type of the ligand. For $\mathrm{d}^{6}$ high spin (four unpaired electron) case, the ground state term is ${ }^{5} \mathrm{D}$ which is split into ${ }^{5} \mathrm{~T}_{2 \mathrm{~g}}$ and ${ }^{5} \mathrm{E}_{\mathrm{g}}$ states so the transition can be assigned to ${ }^{5} \mathrm{~T}_{2 \mathrm{~g}} \rightarrow{ }^{5} \mathrm{E}_{\mathrm{g}}$ while for $\mathrm{d}^{6}$ low spin case, the ground state is ${ }^{1} \mathrm{~A}_{1 \mathrm{~g}}$ and there are two singlet excited states, ${ }^{1} \mathrm{~T}_{1 \mathrm{~g}}$ and ${ }^{1} \mathrm{~T}_{2 \mathrm{~g}}$ and the two observed spectral transitions are assigned as ${ }^{1} \mathrm{~A}_{1 \mathrm{~g}} \rightarrow$ ${ }^{1} \mathrm{~T}_{1 \mathrm{~g}}$ and ${ }^{1} \mathrm{~A}_{1 \mathrm{~g}} \rightarrow{ }^{1} \mathrm{~T}_{2 \mathrm{~g}}$ [21]. The electronic spectrum for synthesized Co (III) complex showed only one band at 22935 $\mathrm{cm}^{-}(436 \mathrm{~nm})$ which is assigned to ${ }^{5} \mathrm{~T}_{2 \mathrm{~g}} \rightarrow{ }^{5} \mathrm{E}_{\mathrm{g}}$ transition with octahedral geometry. Ligand field parameters have also been calculated by Figgis procedure (Table 6).

The magnetic moment of $\mathrm{Mn}$ (II) complex, 5.9BM, consistent with $\mathrm{S}=5 / 2$ ground state in an octahedral field, indicates octahedral geometry of this paramagnetic complex. Absorpition bands in electronic spectrum at $33444 \mathrm{~cm}^{-}(299$ $\mathrm{nm})$ is attributed to charge transfer transition and the band at $27777 \mathrm{~cm}^{-}(360 \mathrm{~nm})$ is due to ${ }^{6} \mathrm{~A}_{1 \mathrm{~g}} \rightarrow{ }^{6} \mathrm{~T}_{1 \mathrm{~g}}(\mathrm{P})$ transition.

Table 6. Electronic absorption spectral and ligand field parameters data.

\begin{tabular}{llllll}
\hline \multirow{2}{*}{ Compounds } & Absorpition region $\left(\mathbf{c m}^{-1}\right)$ & Band assignments & \multicolumn{3}{l}{ Ligand field parameters Racah's parameter } \\
\cline { 5 - 7 } $\mathrm{C}_{14} \mathrm{H}_{13} \mathrm{NO}_{3}$ & 20408 & $\pi-\pi^{*}$ & $\mathrm{C}$ & $10 \mathrm{Dq}$ & $\beta$ \\
$\mathrm{Mn}$ & 2777733444 & ${ }^{6} \mathrm{~A}_{1 \mathrm{~g}} \rightarrow{ }^{6} \mathrm{~T}_{1 \mathrm{~g}}(\mathrm{P}) \mathrm{LMCT}$ & 1130 & 3616 & 12430 \\
$\mathrm{Co}$ & 22935 & ${ }^{5} \mathrm{~T}_{2 \mathrm{~g}} \rightarrow{ }^{5} \mathrm{E}_{\mathrm{g}}$ & & & 0.86 \\
\hline
\end{tabular}

Mn: $\left[\mathrm{Mn}\left(\mathrm{C}_{14} \mathrm{H}_{12} \mathrm{NO}_{3}\right)_{2}\left(\mathrm{H}_{2} \mathrm{O}\right)_{2}\right] \cdot 4 \mathrm{H}_{2} \mathrm{O}, \mathrm{Co}$ : $\left[\mathrm{Co}\left(\mathrm{C}_{14} \mathrm{H}_{12} \mathrm{NO}_{3}\right)_{2}\left(\mathrm{H}_{2} \mathrm{O}\right) \mathrm{Cl}\right] .2 \mathrm{H}_{2} \mathrm{O}$, LMCT: Ligand-metal charge transfer.

Antifungal and Antibacterial Activities of Ligand and Complexes

Bactericidal and fungicidal activities of ligand and its complexes against both bacteria and fungi are dose dependent (Table7). Ligand and its Mn (II) complex showed good activities, slightly lower than the standard reference drug. Antimicrobial, anti-bacterial and anti-fungal actions of all the metal chelates are based on chelation theory. 
Table 7. Antimicrobial activity of synthesized compounds.

\begin{tabular}{|c|c|c|c|c|c|c|c|c|}
\hline \multicolumn{9}{|l|}{ Inhibition zone (mm) } \\
\hline \multirow{3}{*}{ Compounds } & \multicolumn{4}{|l|}{ Fungi } & \multicolumn{4}{|c|}{ Bacteria } \\
\hline & \multicolumn{2}{|c|}{ A. niger } & \multicolumn{2}{|l|}{ Coll. } & \multicolumn{2}{|c|}{ E. coli } & \multicolumn{2}{|c|}{ S. aureus } \\
\hline & $10 \mu \mathrm{l}$ & $20 \mu \mathrm{l}$ & $10 \mu \mathrm{l}$ & $20 \mu \mathrm{l}$ & $10 \mu \mathrm{l}$ & $20 \mu \mathrm{l}$ & $10 \mu \mathrm{I}$ & $20 \mu \mathrm{l}$ \\
\hline $\mathrm{C}_{14} \mathrm{H}_{13} \mathrm{NO}_{3}$ & 26 & 32 & 15 & 25 & 20 & 28 & 22 & 30 \\
\hline Co & - & - & 9 & 16 & - & - & - & - \\
\hline $\mathrm{Mn}$ & 8 & 11 & 18 & 21 & 16 & 24 & 15 & 26 \\
\hline Bavistin (standard) & 27 & 32 & 34 & 36 & - & - & - & - \\
\hline Chloraphenicol (standard) & - & - & - & - & 22 & 30 & 22 & 33 \\
\hline DMSO (control) & 0 & 0 & 0 & 0 & 0 & 0 & 0 & 0 \\
\hline
\end{tabular}

Mn: $\left[\mathrm{Mn}\left(\mathrm{C}_{14} \mathrm{H}_{12} \mathrm{NO}_{3}\right)_{2}\left(\mathrm{H}_{2} \mathrm{O}\right)_{2}\right] .4 \mathrm{H}_{2} \mathrm{O}$, Co: $\left[\mathrm{Co}\left(\mathrm{C}_{14} \mathrm{H}_{12} \mathrm{NO}_{3}\right)_{2}\left(\mathrm{H}_{2} \mathrm{O}\right) \mathrm{Cl}\right] .2 \mathrm{H}_{2} \mathrm{O}$

Bavistin- fungicide used as check Standard for fungi

A. niger - Aspergillus niger

Chloraphenicol- used as check Standard for bacteria

Colletotricum

E. coli-Escherichia coli

S. aureus- Staphylococcus aureus

\section{Conclusions}

The Structural features of these complexes were obtained from their elemental analyses, magnetic.

Susceptibility, molar conductance, FT-IR, electronic spectra, and Atomic Absorption Spectroscopic studies. The FT-IR and UV-Vis data confirm that the Schiff's base ligand binds to the centres via the two $\mathrm{N}$ atoms of azomethine group and two $\mathrm{O}-\mathrm{H}$ groups of the phenolic moiety of the rings. Electronic spectral and magnetic data indicated the paramagnetic nature of both Co (III) and Mn (II) complexes with octahedral geometry. Antimicrobial studies showed that all compounds were effective against both tested bacteria and fungi though their effects are dose dependent. The ligand exhibited highest antifungal and bacterial activities compared to their corresponding complexes.

\section{Acknowledgements}

The Author is thankful to Dr. Yonas Chebude, Chemistry Department, Addis Ababa University for providing all possible help to run magnetic susceptibility measurement and FT-IR spectra.

\section{References}

[1] Abbas, S. A., Munir M., Fatima A., Naheed S. and Ilyas Z. (2010). Synthesis, Characterization and Biocidal Studies of Some Transition Metal Complexes Containing Tetra Dentate and Neutral Bi Dentate Schiff Base. Electronic-Journal of Life Science, 1, 37-40.

[2] El-Mossalamy, E. H., Al-Thabati S. A., Al-Nowalser F. M. and Al-Sulami Q. A. (2005). Solvent Effects on the Electronic Absorption Spectra and Dissociation Costants of Some Sulfa Drugs. Communications Faculty of Sciences University of Ankara Series B, 51, 21-30.

[3] Ying Li., Yang, Z. S., Zhang, H., Cao, B. J. and Wang, F. D. (2003). Artemisinin Derivatives Bearing Mannich Base Group Synthesis and Antimalarial Activity. Bioorganic \& Medicinal
Chemistry, 11, 4363-4368.

[4] Kulandaisamy A. (2003). Synthesis, characterization and Electrochemical Behavior of Acetylacetone and P-anisidine and Their Antimicrobial Activity. Indian Acad Sci, chem Sci, $115,161-167$.

[5] Berg J. M. and Lippard S. J. (2004). Principles of Bioinorganic Chemistry. University Science Books, Mill Valley, CA, USA.

[6] Durga N. D., Saveha P N. and Kumar S., (2000). Application of Metal Complexes of Schiff bases. Journal of scientific and industrial research, 68, 181-187.

[7] Kumari G., Kumari D., Singh, Kumari C. A. and V. B. R. (2010). Synthesis, Physical Characterization and Antimicrobial Activity of Trivalent Metal Schiff Base Complexes. J. Serb. Chem. Soc., 75, 629-637.

[8] Dharmalingam V., Ramasamy A. K. and Balasuramanian V. (2011). Synthesis and EPR Studies of Copper Metal Complexes of Dyes Derived from Remazol Red B, Procino Yellow, Fast Green FCF, Brilliant Cresyl Blue with Copper Acetate Monohydrate. E-Journal of Chemistry, 8, 211-224.

[9] Kumar S., Dhar D. N. and Saxena P. N. (2009). Applications of Metal Complexes of Schiff Base. J. Sci. \& Indu. Res., 68, 181-187.

[10] Villar R., Encio, I., Migliaccio, M., Gil, M. G. and Martinez M. V. (2004). Synthesis and Cytotoxic Activity of Lipophilic Sulphonamide Derivatives of the Benzo [b] thiophene-1, 1-dioxide. Bioorganic \& Medicinal Chemistry, 12, 963-968.

[11] Wang L., Feng, Y., Xue, J. and Li, Y. (2008). Synthesis and Characterization of Novel Porphyrin Schiff Bases. Journal of the Serbian Chemical Society, 73, 1-6.

[12] Wadher S. J., Puranik, M. P., Karande, N. A. and Yeole, P. G. (2009). Synthesis and Biological Evaluation of Schiff base of Dapsone and Their Derivative as Antimicrobial Agents. International Journal of PharmTech Research, 1, 22-33.

[13] Bhat M. A., Imran, M., Khan, S. A. and Siddiqui, N. (2005). Biological Activities of Sulfonamides. Journal of Pharmaceutical Sciences, 67, 151-159. 
[14] Prashanthi Y., and Raj S. (2010). Synthesis and Characterization of Transition Metal Complexes with N,O; N,N and S,N-donor Schifff Base Ligands. J. Sci. Res., 2, 114126.

[15] El-ajaily M. M., Hamil A. M. and Khalifa K. M. (2009). Synthesis, Spectroscopic Investigation and Antibactewrial Activities of Schiff base Complexes of $\mathrm{Co}$ (II) and $\mathrm{Cu}$ (II) ions. Rasayan Journal of chemistry. 2, 261-266.

[16] Kumar G., Kumar D., Singh C. P., Kumar A. and Rana V. B., (2010). Synthesis, physical characterization and antimicrobial activity of trivalent metal Schiff base complexes. J. Serb. Chem. Soc., 75, 629-637.

[17] El-ajaily M. M., Gweirif B. And Morad F. M. (2007). Antibacterial Activity of Ni (II) with Salicyaldehyde and 2amino-benzoic Acid Complex. J. of science and its Appl., 1, $72-78$.

[18] Mapari A. K., and Mangaonkar K. V. (2011). Synthesis,
Characterization and Antimicrobial Activity of Mixed Schiff Base Ligand Complexes of Transition Metal (II) ions. Int. J. Chem. Tech. Res., 3, 477-482.

[19] Prakash A., Singh B. K., Bhojak N. and Adhikari D. (2010). Synthesis and Characterization of Bioactive $\mathrm{Zn}$ (II) and $\mathrm{Cd}$ (II) Complexes with New Schiff Bases Derived from 4nitrobenzaldehyde and Acetophenone with Ethylenediamine. Spectrochimica Acta Part A, 76, 356.

[20] Upadhyay R. K. and Sharama S. (2007). Study in Spincrossover Phenomena in Complexes of Long Chain Ketoanils with Active Methylene group (s) with $\mathrm{Fe}$ (III) and Fe (II), Ph.D. thesis, C. C. S., University, Meerut. J. Bioscience, 2, 2234.

[21] Pandya J. H. and Shah M. K. (2009). Synthesis and Antimicrobial Properties of Transition Metal Complexes of Novel Schiff Base Ligand Derived from 5bromosalicyldehyde. J. Ind. council. Chem., 26, 109-112. 